\title{
Into the Wild Childhood: A Study of Wildness in Three $21^{\text {st }}$-Century Picturebooks ${ }^{1}$
}

\section{Abstract:}

While the majority of the 'wild' children's literature presents male human characters, in the $21^{\text {st }}$ century, there is an increasing tendency to publish texts showing a different kind of wildness. In this article, the author analyses three picturebooks published in the $21^{\text {st }}$ century that feature protagonists other than male and/or human: a wild girl (Wild by Emily Hughes, 2012), a pet dog (Such a Good Boy by Marianna Coppo, 2020), and a wild tiger (Mr Tiger Goes Wild by Peter Brown, 2013). She investigates to what extent (if any) non-male and/or non-human wildness in these works differs from the most popular one in children's literature. The author analyses the concept of wildness in the context of a famous children's picturebook featuring a wild protagonist, Where the Wild Things Are by Maurice Sendak (1963), and other cultural texts using this motif.

Key words:

animals, boys, children's literature, gender, girls, Emily Hughes, Marianna Coppo, Maurice Sendak, Mr Tiger Goes Wild, Peter Brown, picturebooks, Such a Good Boy, Where the Wild Things Are, Wild, wildness

* Anna Mik - MA, works as an assistant in the project Our Mythical Childhood... The Reception of Classical Antiquity in Children's and Young Adults' Culture in Response to Regional and Global Challenges led by Professor Katarzyna Marciniak at the Faculty of "Artes Liberales" at the University of Warsaw (Poland). Contact: anna.m.mik@gmail.com.

1 The research results presented in this paper have been obtained within the project Our Mythical Childhood... The Reception of Classical Antiquity in Children's and Young Adults' Culture in Response to Regional and Global Challenges led by Prof. Katarzyna Marciniak at the Faculty of "Artes Liberales," University of Warsaw, with funding from the European Research Council (ERC) under the European Union's Horizon 2020 Research and Innovation Programme - ERC Consolidator Grant (Grant Agreement No 681202). 


\section{W stronę dzikiego dzieciństwa. Studium dzikości w trzech XXI-wiecznych książkach obrazkowych}

\section{Abstrakt:}

Podczas gdy większość „dzikiej” literatury dziecięcej przedstawia męskie postacie ludzkie, w XXI wieku wzrasta tendencja do publikowania tekstów ukazujących inny rodzaj dzikości. W niniejszym artykule autorka analizuje trzy książki obrazkowe wydane w XXI wieku, w których bohaterowie nie są mężczyznami i/lub ludźmi. Są nimi: dzika dziewczynka (Dzika Emily Hughes, 2012), piesek salonowy (Such a Good Boy [Jaki dobry piesek] Marianny Coppo, 2020) oraz dziki tygrys (Mr Tiger Goes Wild [Pan Tygrys dziczeje] Petera Browna, 2013). Autorka bada, w jakim stopniu (jeśli w ogóle) nie-męska i/lub nie-ludzka dzikość w tych tekstach różni się od tej najpopularniejszej w literaturze dziecięcej. Analizuje pojęcie dzikości w kontekście słynnej książki obrazkowej dla dzieci z dzikim bohaterem, Tam, gdzie żyją dzikie stwory Maurice’a Sendaka (1963), oraz innych tekstów kultury wykorzystujących ten motyw.

\section{Słowa kluczowe:}

zwierzęta, chłopcy, literatura dziecięca, gender, dziewczęta, Emily Hughes, Marianna Coppo, Maurice Sendak, Mr Tiger Goes Wild, Peter Brown, książki obrazkowe, Such a Good Boy, Tam, gdzie żyja dzikie stwory, Dzika, dzikość

\section{Introduction}

$\mathbf{T}$ he founding myth of Rome features three truly wild characters: two baby boys and a she-wolf. The animal found Romulus and Remus in the river Tiber, fed them with her milk, and cleaned them from dirt. As Dionysius of Halicarnassus (ca. $1^{\text {st }}$ c. B.C.E./2014) writes: "When these [shepherds] also drew near and saw the wolf caring for the babes as if they had been her young and the babes clinging to her as to their mother, they thought they were beholding a supernatural sight and advanced in a body, shouting to terrify creature" (pp. 6-7). In the myth, human children were taken care of by a wild animal even though adults were intimidated by the beast. What is more, due to such a wild upbringing, the boys gained strength and were further recognised as divine beings (sons of Mars, the god of war). One interpretation also might be that they were considered divine beings because of the presence of a powerful animal (it should be mentioned that wolves were often associated with Mars; Raaflaub, 2010, p. 143). Later on, the boys did not struggle with human language and were taken care of by a human couple relatively quickly.

Nonetheless, in due course, Romulus and Remus became one of the most popular wild children in the history of (not only) European culture, followed 
by many examples of such boys and girls in the next epochs. The three (the twins and the she-wolf) constitute the 'immortal' cultural image, serving as an allegory of wildness to this day. Ultimately, it might make one wonder - is wildness a universal concept? Is the she-wolf wild in the same way the boys are? Moreover, how does this image relate to the idea of childhood?

As Greek and Roman mythology shows us, the wild has been part of childhood since the antiquity. This case is one of many representations of wild boys in the classical mythology. In the ancient texts, we encounter a fair amount of babies of the male gender who were raised by animals, far from human settlements - such as Zeus, nursed by the goat Amaltheia (March, 2014, p. 43), and Paris, the Trojan prince, fed by a she-bear (Smith, 1858, p. 523). Wild origins of future gods and heroes seem to be valued positively as this phase of childhood was supposed to be necessary and even sacred. It is worth stressing that in most cases it were female animals saving male humans (with the exceptions of stories featuring shepherds taking care of abandoned princes and heroes, e.g. Oedipus). What is more, there are many examples from other mythologies in which children raised by animals appear, to mention an Assyrian myth about a royal baby saved by doves (Moore, 2019). Animal upbringing is not only seen in cases of mythological stories. Throughout the history of the European culture, many wild boys found their way to the popular discourse (Raby, 1997, p. 178): Kaspar Hauser, Peter the Wild Boy, Victor of Aveyron, etc. (grippingly, wild girls were not as popular ${ }^{2}$ ). In each case, to a certain extent, the idea of the 'wild boy,' with his misbehaviour, dirty clothes, unusual ways of communication, opposed the concept of the 'civilised child'.

In numerous studies, researchers focused on wild children from the historical perspective (Benzaquén, 2006; Newton, 2002) or concentrated on the wildness of boys in particular (Kidd, 2004). I would like to suggest a different approach to this topic, already practised in the studies I refer to in this analysis. The main questions would be: Is the wild stimulated by such categories as humanity and gender? How are these three concepts related? ${ }^{4}$ Therefore, in the

2 There were numerous examples of wild girls as well, e.g. Marina Chapman or Marie-Angelique Memmie Le Blanc; however, they were not as popular as boys and, unlike them, their representations do not appear in the mainstream culture as frequently.

3 The whole idea of wild children was also imagined as a specific label made by those who rule the discourse - the adults, which exposes the fact that this notion is inextricably linked with the issue of power relations between the two groups of people. I only mention it here as a context; for more on this topic, see the book by Joseph Zornado (2001).

4 The books analysed in this article can be discussed also as showing the characters' wildness to metaphorically refer to such issues as experiencing the Otherness, the need for 
article, I propose a comparative close reading of three $21^{\text {st }}$-century children's picturebooks featuring wild characters other than a male human child. Firstly, I will attempt to define the boys' wildness in the context of Maurice Sendak's (1963/2000) Where the Wild Things Are - one of the most popular picturebooks of all time, presenting the 'wolf-boy' Max. Then, in the course of the primary analysis, I will study the following picturebooks: Wild by Emily Hughes (2012), Such a Good Boy by Marianna Coppo (2020), and Mr Tiger Goes Wild by Peter Brown (2013), attempting to present three perspectives of wildness: the female, the pet, and the wild animal, ${ }^{5}$ contrasted with the expectations towards the very concept of being wild. By pointing out the features of these picturebooks' main characters, I will attempt to show how their wildness is presented regarding the dominant male wildness (that can be considered toxic or 'healing'; Richardson \& Robinson, 2020, pp. 113-114) and what might be hidden behind the depictions of the four 'misbehaving' creatures.

\section{Wild Children's Literature}

Wild children, as a figure, were already accurately recognised by various scholars (Candland, 1993; Douthwaite, 2002; Landau, 1998; Newton, 2002) who engaged with the discussion on the very concept of the child and its ferocity. Expectedly, the wild child's figure also applies to children's literature (especially created in the West by White people ${ }^{6}$ ) with multiple yet predominantly male human examples. In many works, wildness as such is somehow tamed by the narratives' showing the disadvantages of a wild life and advantages of cultivating a civilised one. In this context, the most classic work would be The

belonging and love, and challenges of meeting the cultural norms. Nonetheless, in my reading, I choose a different path of interpreting them.

5 The concept of girlhood/femininity in children's literature was researched in the context of (inter alia) race, ecocriticms, and queer, in a study by Roberta Seelinger Trites (2018). Pethood studies, children studies, and animals studies, as tools to analyse children's books, were presented in a collective monograph edited by Anna Feuerstein and Carmen Nolte-Odhiambo (2017). Non-human animality, studied in the context of children's literature and posthumanism, was also researched by Zoe Jaques (2015). I do not use these concepts and methodologies directly, nonetheless, I am referring to them here as contexts for my reflections.

6 Literature depicting 'savage' children was, in general, formatted on the basis of white supremacy during the colonial times, which was an effect of imperial politics and racial prejudicies. The 'wild' could have been anything that was strange to White people, perceived by them as 'monstrous' or 'alien,' including non-White people (Fredrickson, 1981, pp. 12-13). In children's literature, it is visible, for example, in Kipling's (1894) The Jungle Book. 
Jungle Book by Rudyard Kipling (1894). Mowgli, the wild boy, raised by wolves and other animals of the Indian rainforest, ultimately returns to humans and learns their ways of living. In this respect, his story inspired later authors to create their narratives featuring wild boys, establishing The Jungle Book as a classic text. The animation of the same title (Reitherman, 1967), produced by Walt Disney Productions (it was also the last film supervised by Walt Disney himself; Smith, 2015, p. 395) and inspired by Kipling's stories, ${ }^{7}$ was an enormous success. It resulted in subsequent productions related to this animation, including sequels, spin-offs, musical versions, and a recent live-action film produced by Walt Disney Studios (Favreau, 2016). Children's literature features many rewritings of The Jungle Book as well. ${ }^{8}$ Stories related to Kipling's work present not only the bond between an animal and a child but also their wildness, common to both.

Kerry Mallan (2018, pp. 227-228), researching the theme, highlights that various texts she analyses ${ }^{9}$ predominantly feature male protagonists, which evokes the need to take a look at characters other than males and other than humans. She argues that children, following the popular view of Sigmund Freud, as well as that of many popular culture texts, are strongly linked to the notion of 'wildness.' What is more, she points out that children's literature is often "associated with the primitive or uncivilised [...]. In this way the child and children's literature become interchangeable with the 'feral' as both stand in opposition to the adult and the civilised" (p. 225). In the analysis, I use the term 'wild' (appropriately: girls, boys, dogs, etc.), not 'feral,' after Adriana S. Benzaquén (2006), who writes:

Wild children are often referred to as 'feral children.' The term has a history: it derives from Linnaeus's 'Homo ferus,' popularised by anthropologist Robert

Amy M. Davis (2013, p. 37) explains that Disney encouraged his crew to interpret the story as they please, hence the author credit for the story goes to four other writers besides Kipling.

8 One of them would be Neil Gaiman's (2008) The Graveyard Book, where a boy called Nobody is raised by ghosts and other monsters in the 'wilderness' of the titled graveyard. There are also two interesting examples coming from Polish children's literature: Miasteczko Ostatnich Westchnień [The Town of Last Sighs] by Grzegorz Gortat (2014), and Strachopolis [Monsteropolis] by Dorota Wieczorek (2015). These books, according to Maciej Skowera (2018a, 2018b), were clearly inspired by Kipling's story, as in both the main characters, boys around the age of 10, are raised by non-human animals (or - their spirits) and monstrous creatures, and both are ultimately introduced to the human world.

9 The Savage by David Almond (2008), The Wild Boy by Mordecai Gerstein (1998), and I Was a Rat! by Philip Pullman (1999). 
Zingg in English as 'feral man,' and later associated exclusively or especially with children. (In some of the recent literature, the purportedly more neutral and inclusive 'isolated children' appears as a substitute for 'feral.') I prefer 'wild children': the notion of 'feral child' conveys an aspiration to a particular type of objectivity and scientificity. Moreover, it conveys the acceptance of a set of assumptions about the proper way to produce knowledge about people, from which I want to distance myself. This aspiration and these assumptions are part of what I set out to investigate (p. 17).

Benzaquén underlines that the concept of the 'feral child' opposes that of the 'normal child' (pp. 17-18). Similar opposition will be used in this article, as I frequently point out the contrast between nature and civilisation present in the analysed texts. However, what I would also like to highlight is that the boundaries between nature and culture, wildness and civilisation (but also of childhood and adulthood, not discussed here in detail), are blurred.

In the analysed works, what is wild is not necessarily abnormal or, at least, is not negatively perceived. I will focus on the following characteristics of and/ or assumptions about the depictions of wild creatures in literature:

- Wild creatures live in forests or other natural habitats, outside of human settlements;

- They are raised by wild animals that take the roles of parents;

- Due to their wild upbringing, they do not speak human language, which would be one of the essential features of the civilised child;

- By extension, it is natural for children, in general, to acquire non-human animal behaviour: they howl, bark, bite, hunt, etc.

- In general, they are strongly associated with nature; opposing culture in almost every aspect as its representatives.

Even though not all elements listed above may occur in the stories, the absence of a particular feature might point to the alternations in the contemporary perception of wildness. Bearing all of this in mind, I will now move to the analysis of the aforementioned picturebooks. Thanks to the "sophisticated textual interplay" (Johnston, 2011, p. 86) they offer, I will read (pp. 88-89; Reynolds, 2011, p. 57) equally important texts and images in which the wild is coded (Johnston, 2011, p. 86). I have chosen the listed works because, in my view, they present a variety of approaches to wildness in $21^{\text {st }}$-century picturebooks directed at the youngest readers. By emphasising what really stands behind the figure of the (non-male and/or non-human) Other, hopefully, I will highlight the importance of such characters in children's literature. 
Wild Creatures in Picturebooks: The Boy, the Girl, the Dog, the Tiger

Where the Wild Things Are by Maurice Sendak (1963)

Maurice Sendak's (1963/2000) Where the Wild Things Are is probably one of the most famous children's books on boys' wildness. Here, the wild is represented by the child's rebellious attitude and animality which contrast with the domestic environment. From the first pages of the picturebook, the main character, a boy named Max, wears a wolf suit (we see him in the costume from the beginning of the story on the illustrations, p. [3]) and makes "mischief of one kind and another" (p. [2]). At the very beginning:

\section{[...] his mother called him "WILD THING!" and Max said "I'LL EAT YOU UP!" \\ so he was sent to bed without eating anything (p. [6]).}

It is an instant definition of the boy's wildness, built upon three elements: the animality (as animals culturally were and sometimes still are equalled with evil; Alaimo, 2010; Jacques, 2015; Soper, 1995) - he dresses up as a wolf and imitates this animal; the misbehaviour - he opposes the rules of being a well-reared child; and the hunger - he claims he will eat his mother (yet, ultimately, the boy is sent to his room without dinner). These three components are not only the foundation of Max's wildness, but they became the archetypical features of the wild child in later texts (including the works analysed in this article).

Max's wildness, constructed on those aspects, initiates the growth of a forest inside the house (we see how the forest overtakes the space of Max's room on the illustrations; Sendak, 1963/2000, p. [9], [11]). The wild takes over the civilised by dominating not only space but also time, which now seems to stand still. Moreover, the bedroom 'opens' - the walls and floor disappear - and now Max can travel on his boat over the sea (pp. [14-15]). The motif of travel itself matches the concept of wildness - Katarzyna Slany (2016) claims that Max's travel is a classic representation of the child's escape from home which restricts their potential (p. 242). What is more, according to Kenneth B. Kidd (2004), during the second half of the $20^{\text {th }}$ century, the cult of domesticity was spreading among both women and men (p. 156). Following such an observation, two aspects of male wildness are exposed. On the one hand, in Max's departure, Kidd sees the absence of a father, which opens the interpretation for the boy's wildness which would stand for rebellion against a missing parent (p. 156). On the other hand, male wildness might be associated with other characteristics than those traditionally assigned to men (toxic masculinity, hypermasculinity, 
hegemonic masculinity, etc.; De Dauw, Connell, 2020, pp. 3-5), as their natural environment is not the wilderness anymore, but a loving home.

Max lands on an island inhabited by the Wild Things. They do not resemble any particular creatures nor animals. Instead, they present themselves as monstrous hybrids, imagined by the boy (the suggestion for that is illustrated on page [5] in the book by Sendak, 1963/2000, where we see the picture of a Wild Thing drawn by Max and pinned to the wall). Immediately, the reader might observe that the wildness of the creatures does not differ from the boy's as much: they are all loud and somewhat aggressive towards one another. Some other features of the Wild Things are highlighted: roaring, teeth-gnashing, eyerolling, and showing the claws (pp. [18-19]). Their wildness is, therefore, more of a monstrous kind than Max's, as if the child only imitated the behaviour of truly wild creatures. Ultimately, Max only wears a costume of a wild animal; he does not have sharp teeth, no claws, nor horns. His 'uncivilised' behaviour mostly defines his wildness. ${ }^{10}$

From the very beginning, Max attempts to dominate the group by commanding: "BE STILL!" (Sendak, 1963/2000, p. [20]) and overpowers the monsters. From now on, the Wild Things "called him the most wild thing of all and made him king of all wild things" (pp. [21-22]), and became friends with the boy. On the next pages, we observe they spend time together on wild activities (climbing the trees, howling to the moon). However, eventually, Max feels lonely and wants "to be where someone loved him best of all" (p. [30]) - 'wild love' is not sufficient for the boy. Presumably, he misses his mother and favours her presence to the Wild Things that do not provide him love and warmth, or maybe most importantly - food. Max's wildness, established earlier and based on animality, misbehaviour, and hunger, is fulfilled only in two first parts while being with the Wild Things. The hunger stays unsatisfied, and for his wildness to be fulfilled, Max has to go back home.

This need to satisfy the hunger is vividly expressed in the following lines: "Then all around from far away across the world he smelled good things to eat so he gave up being king of where the wild things are" (Sendak, 1963/2000, p. [31]) and "[...] his supper [was] waiting for him and it was still hot" (p. [36], [38]). The food provided by his mother is a reward for taming (colonising) his wildness, the food also provides him a place in the family's hierarchy and stands for the end of the process of civilisation (AbdelRahim, 2015, p. 89). In the last picture, we see that Max starts to take off his wolf costume as he rejects the

${ }_{10}$ In the film adaptation (Jonze, 2009), and the novel version (Eggers, 2009), the psychological aspects and some parts of the picturebooks are developed. 
wildness or passes this stage of his development (Sendak, 1963/2000, p. [37]). Up to this point, being a wolf, imitating its behaviour, and even becoming the animal defined the boy's wildness, which can be read in the light of Sigmund Freud's psychoanalytical theories: as Kidd (2011, pp. 224-225) suggests, it could be a realisation of The Wolf Man figure. Nonetheless, even though Sendak's stories could be read as a 'bad boys' metaphor, Kidd leans towards a theory as if Where the Wild Things Are was more of a queer story than a picturebook presenting traditional gender roles (pp. 225-226), which puts the 'boy wildness' in yet another perspective, or even questions the construct of boyhood itself. ${ }^{11}$

The child goes back to the world of culture (his room) where there is no sign of the forest anymore. The wildness, represented by the Wild Things, is not favoured to the warmth of home and motherly love. It is shown as an essential and needed part of childhood (or only its episode, a temporary state); however, after the wild is expressed and experienced, it is then time to go back to the state of culture. As Kidd (2004) points out, the book "makes inner wildness utterly safe" (p. 156), regarding boys' queerness particularly. Would it be the case of girls' wildness as well?

\section{Wild by Emily Hughes (2012)}

The answer to this question is to be found in a much later story, as it would seem before the $21^{\text {st }}$ century, the topic of girls' wildness was not very popular among the writers for children. Although there indeed were misbehaving or wild girls also in the $19^{\text {th }}$ and $20^{\text {th }}$ centuries, ${ }^{12}$ none of them was as wild as the main character of Wild, a picturebook by Emily Hughes (2012). The wildness is a baseline for the story of a little girl living in the forest, among animals (this time - those existing, like a bear, a fox, etc.). As we read at the beginning: "No one remembered how she came to the woods, but all knew it was right.

11 Another contexts for Where the Wild Things Are are postcolonial studies. As John Clement Ball (1997) writes, “[...] Sendak presents his readers with a time-honoured narrative of empowerment. Yet while he draws on attitudes and structures associated with discredited modes of colonialist and racist thinking, it would be wrong to accuse Where the Wild Things Are of being nefariously colonialist or racist book" (p. 177). Max can be seen as a White conqueror subjugating a foreign nation. Nevertheless, it is worth remembering that this is primarily a story about the nature of childhood (which does not exclude postcolonial interpretation but rather complements it).

12 With a little robber girl form The Snow Queen by Hans Christian Andersen (1844/2005), the not always well-mannered protagonist from Anne of Green Gables by Lucy Maud Montgomery (1908), Pippi Longstocking or Ronia, created by Astrid Lindgren (1945/1988, 1981/1985). 
The whole forest took her as their own" (p. [2)]. There is no starting point of the story that would take place at a home or a city - just like Romulus and Remus, the girl belonged to the wild since she was a baby. The motif of an infant left in the woods and raised by animals also brings back Kipling's The Jungle Book to one's mind. Unlike in Sendak's story, the girl knows the wild before the civilised. Unlike in all the stories mentioned above, she does not have a name. Moreover, unlike most of the textual wild boys, she is completely naked. Even though her breasts and lady parts are covered (by hair, leaves, etc.), she contrasts with Max (whose costume not only covers the boy but also transforms him into a wolf). The girl's wildness is authentic, prime, naked.

The connection to the wild animals has been instantly established: "Bird taught her how to speak. Bear taught her how to eat. Fox taught her how to play. And she understood, and was happy" (Hughes, 2012, pp. [5-10]). The education and upbringing of the child, usually provided by human parents within the cultural structures, here is realised by animals and nature. None of the pictures accompanying the text shows the girl anxious or scared - she always has a smile on her face and feels comfortable. Again, the girl's wildness is built upon different features than Max's, even if they stay in close relation: on the ability to speak, to hunt, and to interact with others. Max howled with the Wild Things and positively interacted with them, however, as it was already established - his hunger was not satisfied in the wild. In Hughes's story, the girl also fulfils this basic need, which establishes her place among wild creatures.

The girl's happy life in the woods is interrupted when two people find her, sitting alone on the ground. Their faces express concern (Hughes, 2012, p. [12]), but also fear - we read that: "They found her strange..." (p. [14]). The girl does not look happy sitting in the car next to her questionable saviours - "she found them strange too" (p. [15]). The child ends up in the room with two different people examining her - on the illustration, we can read from the newspaper headline: "Famed Psychiatrist Takes in Feral Child" (p. [16]). Expectedly, the wild girl is perceived by people of culture as a curiosity, and that seems to irritate the child. On the next pages, she is already in a dress and shoes; her hair is combed, the famed psychiatrist takes notes. She does not look scared - just angry and impatient, waiting for the mockery to be over (p. [16]). "They did everything wrong!" (p. [16]), the text says. "They spoke wrong” (p. [18]) - she only could say: "Kraw" (p. [19]). "They are wrong" (p. [21]) - she devoured the steak straight from the plate (p. [20]). "They played wrong” (p. [23]) - she enjoyed ripping all the pretty toys apart and make a big mess (p. [22]). The 'mistakes' listed in the text are accompanied by the illustrations, showing the exemplification of the wild girl's behaviour, wrong according to the civilised ones, and right 
- according to the rules of wildness. The inversion of the narrative perspective shows the relativity of norms adopted by adults and misevaluation of the 'civilised' behavior. The following line says: "And she did not understand, and she was not happy" (p. [25]). Next, there is the first illustration where we see the girl scared, hiding under her bed (p. [24]).

The (mis)understanding between the wild girl and the people of culture is the book's central issue - just as it was, to a certain extent, in Where the Wild Things Are. However, the solution is entirely different. "Enough was enough!" (Hughes, 2012, p. [26]), the text says when the girl decides to return to the wild. She destroys the house she was kept in: illustrations show the furniture is broken, curtains - ripped, and windows - shuttered (pp. [26-27]). Unlike the appearance of the girl in the woods, her escape is quite spectacular: "Everyone remembered how she left, and all knew it was right" (pp. [30-31]). Also, unlike in Sendak's story, the rebellious moment comes later in the narrative, and the escape to the wild is final. For the girl, there is no warm supper waiting for her in her bedroom, no parents to be missed - she does not need a human family. Instead, animals are waiting for her in the woods, not a house. What is more, unlike Max, the wild girl does not only dress up as an animal - she is one, in the sense of animalistic femininity. Reunited with her family, she is joyful. What is more, unlike in Max's case, the wild temper stays with the main character - for it is not a costume, she is a wild thing: "Because you cannot tame something so happily wild..." (p. [33]).

As Maija-Liisa Harju and Dawn Rouse (2017) point out, Hughes's picturebook "vividly denounces the historical, psychoanalytic, social, and educational construction of the child as a wild thing needing to be tamed by civilisation" (p. 454). What is more, Wild presents the feminine version of wildness, opposing the male (or, in Kidd's reading, queer) one projected by Sendak in Where the Wild Things Are (taking into consideration the time that separates Sendak's picturebook from Hughes's). For example, comparing depictions of the main characters on the illustrations, we observe different approaches to the concept of 'dressing-up.' Max wears a costume of a wolf to evoke his animal side, moreover - he wears a crown to establish his power over the Wild Things. In Hughes's story, the girl is wild because she does not wear any clothes or costumes. She has green, tangled hair, resembling leaves and bringing her even closer to nature. On the graphic level, Max's animality seems to be faked, whereas the girl appears genuinely and permanently wild. She does not have claws or big eyes; she does not roar or does not make any scary noises like Max and the Wild Things. According to Harju and Rouse, "the author does not merely reinforce the past construction of the child in nature as an innocent" (p. 455). What is 
more, as Marcela Terrusi (2018) highlights, Wild "does not offer stereotypical images but a more controversial and ambivalent portrait of a female character who determines her destiny" (p. 87). The wild girl is wild by nature, whereas Max's wildness originated in the civilised world.

\section{Such a Good Boy by Marianna Coppo (2020)}

Interestingly, both of these wild characters, Max and the wild girl, are accompanied by other creatures - dogs. In Where the Wild Things Are, Max (still at home) chases a dog (Sendak, 1963/2000, p. [5]), and this action is considered as one of his 'mischiefs.' However, the dog does not participate in the boy's wild adventures. In Wild, the character accompanying the girl escaping the civilised world is also a dog, happily joining the protagonist. The reader meets the animal for the first time in the psychiatrist office, where the child is examined. The dog looks scared and concerned for the young patient (Hughes, 2012, p. [17]). However, on the next pages, it enjoys the wild girl's company: it discovers that, just like her, it does not understand human language, it loves to eat without utensils, and when they play together, they make a lot of mess (pp. [20-22]). The dog is just as wild as the girl, and accordingly - they both do not belong to the world of culture. Ultimately, the girl escapes the human house with the dog - depicted as happy and free. In the next picturebook, Such a Good Boy by Marianna Coppo (2020), the wildness of a dog is rediscovered in yet another way.

The titled 'good boy' is Buzz, a little white dog, probably a Maltese (dogs popular for their fluffiness and well-developed 'pet' behaviour; presumably, they make very good pets). Buzz is considered to be "a very lucky dog. He lives in a very fancy house inside an even fancier one" (Coppo, 2020, pp. [4-5]). From the human's perspective, Buzz "pretty much has it all" (p. [7]) - he gets the best food, his fur is taken care of with the best products and perfumes (which cause him more pain than pleasure; Baratay, 2012/2016, p. 253), he has all the toys and costumes. However, in the pictures, Buzz is presented as not very happy and does not appreciate his wealth (Coppo, 2020, pp. [4-9]). The text contrasts with illustrations, creating an ironic depiction of Buzz's life. $\mathrm{He}$ "feels under pressure. He has to keep up the family name" (pp. [8-9]) - the family of dogs who were such good boys and girls before him. Henceforth, he tries to obey his owner and does not follow his instincts to pee on hydrants or smell other dogs' excrements (p. [11]). Being a good boy, for Buzz, means not to being a dog at all.

Buzz does not get to experience a dog's life in its fullest - he rather ought to behave like an accessory or a toy, which would be a popular approach of 
a human to a dog being just an object, not a subject (Baratay, 2012/2016, p. 247). The illustrations show that as well: Buzz resembles a stuffed animal, fluffy and adorable, beautifully fitting in his owner's home (Coppo, 2020, pp. [3-4]). Visually, he fits this world perfectly, but such a depiction is misleading. We are aware of his sadness because of the text (which is ironic, considering the fact that the dog would never communicate with us via words). However, he is allowed to observe the other dogs' lives on Sundays, when he and his owner go to the dog park. There, he sees dogs running around, playing with each other, barking, and swimming in the pond. Buzz himself is not allowed to enter the park because he has been told (probably - by his owner) that the dogs there are "dangerous," "wild," and "mean" (p. [12]). The park represents Buzz's dream of being a 'real' dog. He cannot seize it, so he sometimes "wishes he were someone else" (p. [16]). Buzz feels entirely deprived of his rights. The suspicion and maybe even hope occurs that there is a way out of his miserable situation.

The rebellious moment, just like in Hughes's Wild, comes in the second part of the picturebook, even though, again, there is civilisation appearing first, wildness - second. On the next page, when Buzz sees a puddle, he cannot resist the temptation and jumps right into it, getting all wet and dirty (Coppo, 2020, pp. [20-21]). "No, no, NO! Don't you dare, Buzz!" (p. [20]), screams the owner. "Well, he does" (p. [21]) - and, as the illustration shows, is very happy about it. He gets punished for his mischief and is taken to a pet groomer, where he is cleaned and decorated with pink ribbons (pp. [22-23]). However, that is just a failed attempt to erase the dog's wildness. Using the moment of the owner's absence, he follows the bird he sees outside the window. "Good boy?" (p. [26]), he seems to wonder. „Not anymore” (p. [27]) - and he escapes the human world. "Buzz is free!" (p. [28]).

Buzz runs to his favourite place that he has never explored - the dog park. Now, he is "free to run. Free to stop. Free to recognise and be recognised" (Coppo, 2020 , pp. [30-31]). He sniffs whatever he wants and pees whenever he pleases. He can finally taste everything that surrounds him and digs many holes, as any dog would love to do. Buzz gets very dirty in the process, loses his leash and pretty pink ribbons (pp. [32-33]). Eventually, he does not resemble the dog whose pictures appeared on the posters ("Lost Buzz"; pp. [34-39]) put all over the town by the concerned owner. He cannot come back to his home, or at least, as the last picture suggests, he could stay outside while being replaced by a pretty, white, and miserable cat. Buzz is now wild and free, living outside (it is not specified where).

The dog's wildness comes second to his tamed state. On the one hand, just like in Sendak's story, the main character wants to be wild (also methaphorically, 
longing for authenticity) but is forbidden to do so by his caretaker. On the other hand, just like in Hughes's book, the wild state is valued positively not just as something temporary, but as a natural habitat of the protagonist. What is more, in Coppo's story, wildness is explicitly equated with freedom, which, as such, did not appear in the previous examples. Even though Buzz was not taken from the wild like the wild girl, he feels an urge to be reunited with his true nature. The cultural model of a house pet enforced by humans is rejected. Buzz's wildness is defined through freedom to be a dog: to run free, get dirty, dig a hole, pee on a tree, play with other animals. The last feature - the connection to other non-human animals - seems to apply to human wildness as well.

\section{Mr Tiger Goes Wild by Peter Brown (2013)}

Nonetheless, those wild characters, Sendak's boy, Hughes's girl, and Coppo's $\mathrm{dog}$, are creatures that are primarily assigned to live within human society, even if their wild sides tell them otherwise. Therefore, I would like to recall one last example featuring the wildness in its truly primal aspect, the closest to the concept of wildness present in the myth of Romulus and Remus. $\mathrm{Mr}$ Tiger Goes Wild by Peter Brown (2013) is a picturebook about a creature that belongs to the wild - namely, a tiger. The book opens with the illustration of anthropomorphised animals living in the city resembling $19^{\text {th }}$-century London, not only wearing clothes and having the upright posture but also proud (with their eyes closed) and distanced - except for Mr Tiger, who seems to be quite angry (pp. [2-3]).

"Mr Tiger was bored with always being so proper" - says the texts accompanying the illustration on which Mr Tiger is having tea with an elephant and a rhino (Brown, 2013, p. [4]). He cannot stand polite conversations about the weather and is annoyed when the horse teacher humorously screams at children (a little rhino, a bear, and a pig): "Now, children, please do not act like wild animals" (p. [5]). Mr Tiger "wanted to loosen up [...] to have fun [...] to be... wild" (p. [7]) - at this point, he does not want to behave appropriately, accordingly to human standards - just like the good boy, Buzz. Hence, one day he has "a very wild idea" (pp. [8-9]) to stand on all four paws, not only on the back two, like he used to. His wild behaviour was expressed through running, playing with other wild beasts (misbehaving children) and roaring (p. [15]) just like the Wild Things. Mr Tiger crosses the line when he loses his clothes (common motif for Brown and Hughes) and is exiled by the city: "If you must act wild, kindly do so in the WILDERNESS!" (p. [22]). The tiger likes this idea and pursues it right away (p. [23]). 
Outside of the city, he goes "completely wild" (Brown, 2013, p. [28]) and is relatively content, up to the point when he starts feeling lonely (p. [33]). He decides to return to the city, wearing some clothes but continues to walk on four paws. However, he is now not the only one - some other animals began to walk on four legs as well. In the end, as we see on the illustrations, the majority of animal citizens become almost wholly wild, some of them still having hats on their heads (pp. [36-37]). The wildness of the characters means to be free, to be oneself, as the text informs the reader (pp. [38-40]). For animals, it means not to wear clothes and run on four legs, as we see in the illustrations (pp. [39-40]). The depiction of a wild tiger brings it closer to the wild things (monstrous creatures), to the wild girl, and good boy Buzz. These creatures celebrate their wildness and simultaneously want to maintain that state, while for Max, it is instead a phase, after which he gladly goes back to the civilised world.

Additionally, Mr Tiger represents any anthropomorphised wild animal of children's literature - walking on two legs, wearing clothes, behaving like a human. The norm in this world is to be a human and suppress animal instincts, seen as incorrect or even rude. Brown seems to make a point on this issue and advocate for a wild creature which should be wild, also in children's books. ${ }^{13}$

\section{Conclusions}

The $21^{\text {st }}$-century picturebooks analysed in this article represent three visions of wildness. In Hughes's story, being wild is being happy - it is the culture that restricts children from being free, playful, and peaceful. Unlike Sendak's wildness, Hughes shows this it a natural state, not a temporary outburst or escape. Coppo's character in Such a Good Boy would represent the hidden wildness of pet animals, domesticated by humans, often deprived of their instincts. Although Buzz does not go wild completely (he still lives nearby his owner's house), he is allowed to be a dog - even if it is a messy and not very glamorous

13 Freed of humanity, animals can not only teach the youngest about the environment or biodiversity, but they can also show them how to be truly wild. What is worth mentioning, Brown (2016) wrote another story about being wild: The Wild Robot. This is not a picturebook, hence it is not a part of the main analysis. It concerns the wildness of a female robot, Roz, who adapts to live in the wild by observing wild animals and behaving like them. She also learns to understand the language of animals. Her wildness is secondary to a 'normal' behaviour, unlike in the cases of Sendak's or Hughes's characters. This brings the issue of wildness to another level - it is not a systemic change that is expected by the author, but internal transformation of the main character who wants to adjust to new circumstances. 
life. Here, wildness is freedom. As the next author proves, wild tigers of children's literature should be free as well. Just like in Brown's story, Mr Tiger Goes Wild, children's literature should not only 'imprison' non-human animals in a human form. Freeing wild characters from harmful stereotypes generated by culture can contribute to a paradigm shift and start an era of wildness in which no one will feel isolated - nor will require isolation. In Brown's story, being wild is to be one's true self. In all these stories, both culture and civilisation constitute a cage for the main characters. These works show how the concepts of animality, gender, and wildness are closely linked. All creatures related to these concepts are presented as excluded beings, misunderstood by the dominant group - in these cases, adults. They clearly influence each other, the Others conjugated in a seemingly interdependent paradigm. Nonetheless, 'freed' wildness comes with the joy of life, liberated from cultural expectations. In contemporary picturebooks, wildness is something, most of all, positive, even if still perceived as strange.

As Mallan (2018) argues: “Children's literature continues to exploit the idea of 'wild' children and their potential for disrupting normality" (p. 226). A wild child is a model of behaviour that corresponds to upbringing strategies. A cultural child would be the ideal child, ready to be introduced to society. However, the presented picturebooks, in my opinion, blur the line between wildness and civilisation, showing that this distinction is maybe not entirely accurate. The wild creatures of these works break the rules of this division and seem happy when not assigned to any particular order. Little girls love being wild, fluffy dogs love to get dirty, and wild tigers love to be on their four feet, with no clothes on. Sidney I. Dobrin and Kenneth B. Kidd (2004), researching wild children in the context of ecocriticism, convince us: "Close contact with nature can be dangerous, but so, too, can our evasion and denial of it" (p. 2). Celebrating wildness in children's literature, just like celebrating the Otherness, can revolutionise not only thinking about the child but also thinking about humanity in general; not in opposition to culture, but to harmful stereotypes, regarding femininity or animality. Picturebooks by Hughes, Coppo, and Brown break the patterns and show wildness in its best form - open to the joy of life. After all, just like in the myth of Romulus and Remus, the only ones afraid of the wild are the adults. ${ }^{14}$

14 There is a possibility that adult characters of this myth were afraid of the wild creatures due to the religious reasons. As I have pointed out at the beginning of the article, animals were often associated with the gods, and as such might have stirred up fear. 


\section{References}

AbdelRahim, L. (2015). Children's literature, domestication, and social foundation: Narratives of civilization and wilderness. Routledge.

Alaimo, S. (2010). Bodily natures: Science, environment, and the material self. Indiana University Press.

Almond, D. (2008). The savage. Walker Books.

Andersen, H. C. (2005). The Snow Queen. In The stories of Hans Christian Andersen (D. C. Frank \& J. Frank, Trans.). Duke University Press. (Original work published 1844).

Baratay, É. (2016). Zwierzęcy punkt widzenia. Inna wersja historii (P. Tarasewicz, Trans.). Wydawnictwo w Podwórku. (Original work published 2012).

Benzaquén, A. S. (2006). Encounters with wild children: Temptation and disappointment in the study of human nature. McGill-Queen's University Press.

Brown, P. (2013). Mr Tiger goes wild. Macmillan.

Brown, P. (2016). The wild robot. Little, Brown.

Candland, D. K. (1993). Feral children and clever animals: Reflections on human nature. Oxford University Press.

Coppo, M. (2020). Such a good boy. Chronicle Books.

Davis, A. M. (2013). Handsome heroes \& vile villains: Men in Disney's feature animation. Indiana University Press.

De Dauw, E., Connell, D. J. Eds. (2020). Toxic masculinity: Mapping the monstrous Other in our heroes. University Press of Mississippi.

Dionysius of Halicarnassus. (2014). Roman antiquities (E. Cary, Trans.). Harvard University Press. (Original work published ca. $1^{\text {st }}$ c. B.C.E.).

Reitherman, W. (Director). (1967). The jungle book [Motion picture]. Walt Disney Productions \& Buena Vista Distribution.

Dobrin, S. I, \& Kidd, K. B. (Eds.). (2004). Wild things: Children's culture and ecocriticism. Wayne State University Press.

Douthwaite, J. V. (2002). The wild girl, natural man, and the monster: Dangerous experiments in the Age of Enlightenment. University of Chicago Press.

Eggers, D. (2009). The Wild Things: A novel. McSweeney's Books.

Favreau, J. (Director). (2016). The jungle book [Motion picture]. Walt Disney Studios Motion Pictures.

Feuerstein, A., \& Nolte-Odhiambo, C. (Eds.). (2017). Childhood and pethood in literature and culture: New perspectives on childhood studies and animal studies. Routledge.

Fredrickson, G. M. (1981). White supremacy: A comparative study in American and South African history. Oxford University Press.

Gaiman, N. (2008). The graveyard book. HarperCollins. 
Gerstein, M. (1998). The wild boy: Based on the true story of the wild boy of Aveyron. Farrar.

Gortat, G. (2014). Miasteczko Ostatnich Westchnień. Ezop.

Jonze, S. (Director). (2009). Where the Wild Things are. Warner Bros.

Harju, M.-L., \& Rouse, D. (2017). "Keeping some wildness always alive”: Posthumanism and the animality of children's literature and play. Children's Literature in Education, 49, 447-466. https://doi.org/10.1007/s10583-017-9329-3.

Hughes, E. (2013). Wild. Flying Eye Book.

Jaques, Z. (2015). Children's literature and the posthuman: Animal, environment, cyborg. Routledge.

Johnston, R. R. (2001). Analyzing visual texts - tools and terminologies. In: M. O. Grenby \& K. Reynolds (Eds.), Children's literature studies: A research handbook (pp. 82-90). Palgrave Macmillan.

Kidd, K. B. (2004). Making American boys: Boyology and the feral tale. University of Minnesota Press.

Kidd, K. B. (2011). Wild Things and wolf dreams: Maurice Sendak, picturebook psychologist. In J. L. Mickenberg \& L. Vallone (Eds.), The Oxford handbook of children's literature (pp. 211-230). Oxford University Press.

Kipling, R. (1894). The jungle book. Macmillan.

Landau, E. (1998). Wild children: Growing up without human contact. Franklin Watts.

Lindgren, A. (1985). Ronia, the robber's daughter (P. Crampton, Trans.). Puffin Books. (Original work published 1981).

Lindgren, A. (1988). Pippi Longstocking (F. Lamborn, Trans.). Puffin Books. (Original work published 1945).

Mallan, K. (2018). The wild child: Posthumanism and the child-animal figure. In N. Goga, L. Guanio-Uluru, B. Oddrun Hallås, \& A. Nyrnes (Eds.), Ecocritical perspectives on children's texts and cultures: Nordic Dialogues (pp. 225-239). Palgrave Macmillan.

March, J. (2014). Dictionary of classical mythology ( $2^{\text {nd }}$ ed.). Oxbow Books.

Montgomery, L. M. (1908). Anne of Green Gables. L. C. Page.

Moore, E. (2019). W. S. Gilbert and the context of comedy: The progress of fun. Routledge.

Newton, M. (2002). Savage girls and wild boys: A history of feral children. Faber and Faber.

Pullman, P. (1999). I was a rat! ...or the scarlet slippers. Doubleday.

Raaflaub, K. A. (2010). Between myth and history: Rome's rise from village to empire (the eighth century to 264). In N. Rosenstein \& R. Morstein-Marx (Eds.), A companion to the Roman Republic (pp. 125-146). Blackwell.

Raby, P. (1997). Bright paradise: Victorian scientific travellers. Princeton University Press. 
Reynolds, K. (2011). Children's literature: A very short introduction. Oxford University Press.

Richardson, D., \& Robinson, V. (2020). Introducing gender and women's studies ( $5^{\text {th }}$ ed.). Red Globe Press.

Sendak, M. (2000). Where the Wild Things are. Red Fox. (Original work published 1963).

Skowera, M. (2018a). Strachopolis [Monsteropolis]. In K. Marciniak (Ed.), Our mythical childhood survey. Retrieved December 30, 2020 from http://www.omc.obta. al.uw.edu.pl/myth-survey/item/501.

Skowera, M. (2018b). The Town of Last Sighs [Miasteczko Ostatnich Westchnień]. In K. Marciniak (Ed.), Our mythical childhood survey. Retrieved December 30, 2020 from http://www.omc.obta.al.uw.edu.pl/myth-survey/item/507.

Slany, K. (2016). Groza w literaturze dziecięcej. Od Grimmów do Gaimana. WN UP.

Smith, D. (2015). Disney A to Z (fourth edition): The official encyclopedia. Disney Editions.

Smith, W. (1858). A classical dictionary of biography, mythology, and geography: Based on the larger dictionaries. John Murray \& Walton and Maberly.

Soper, K. (1995). What is nature?: Culture, politics and the non-human. Wiley-Blackwell.

Terrusi, M. (2018). The green ship: Reading through branches and waves. Growing outdoors with contemporary children's picturebooks. Encyclopaideia, 22(50), 7991. https://doi.org/10.6092/issn.1825-8670/7920.

Trites, R. S. (2018). Twenty-first-century feminisms in children's and adolescent literature. University Press of Mississippi.

Wieczorek, D. (2015). Strachopolis. Skrzat.

Zornado, J. (2001). Inventing the child: Culture, ideology, and the story of childhood. Routledge. 